\title{
L-005 幼児における計算能力と手指の巧緻性の関係
}

\author{
講演者：浅川 淳司 (広島大学) \\ 司会者: 杉村伸一郎 (広島大学)
}

本研究では, 手指の運動的側面である巧緻性（器用さ）に焦点をあて計算能力との関係およびその発 達について幼児を対象に検討した。その結果, 数の操作という高次の認知機能が完全に抽象化されてい るのではなく, 手指やその運動を内包していることが示唆された。具体的には, 第 1 に, 従来の研究で 計算能力との関係が示唆されてきたワーキングメモリより手指の巧緻性の方が計算能力と強く関係する ことを示した。第 2 に, 手指の巧緻性が 1 年半後までの計算能力を予測し, 実際に計算能力と手指の巧 緻性が個人内で共変することを示唆した。第 3 に, 手指の巧緻性はカウンティングを介して計算能力と 関係しており，数をかぞえる際にうまく手指を動かせることでカウンティング概念の獲得が促進され， 計算能力も向上することを示唆した。以上より, 認知発達を検討する際に, 認知的な要素のみで検討す るのではなく，身体や運動などを含めて包括的に捉えていく必要がある。 